Tohoku J. exp. Med., 1983, 141, Suppl., 563-568

\title{
Tolbutamide Effect on Cultured Human Endothelial Cells with Special Reference to Platelet Aggregation
}

\author{
Kenji Kawaguchi, Yasuhiro Oribe and Haruo Uzawa \\ Department of Internal Medicine, Institute of \\ Constitutional Medicine, Kumamoto University, Kumamoto \\ 862, Japan
}

KaWaguchi, K., OrIBE, Y. and Uzawa, H. Tolbutamide Effect on Cultured Human Endothelial Cells with Special Reference to Platelet Aggregation. Tohoku J. exp. Med., 1983, 141, Suppl., 563-568_- Since the UGDP report, there have been many discussions on tolbutamide in relation to arterial metabolism. In view of this, we investigated the effect of tolbutamide on endothelial cells using ADPinduced platelet aggregation. We followed Gimbrone's method of cell culture and after the addition of tolbutamide, a platelet aggregation test was performed. 100 $\mu \mathrm{M}$ tolbutamide showed no inhibitory effect on platelet aggregation, but $1 \mathrm{mM}$ tolbutamide effected a $25 \%$ decrease in aggregation. These results suggest that tolbutamide does not inhibit prostacyclin synthesis of endothelial cells at conventional dosages. —— tolbutamide ; cultured endothelial cells ; platelet aggregation; prostacyclin

The usefulness of oral hypoglycemic agents in the treatment of diabetes mellitus has been controversial since the initial reports of enhanced cardiovascular mortality (UGDP 1970 ; Policy Statement 1979). Although the effects of tolbutamide on the heart have been examined in animals (Lasseter et al. 1972) and man (Hildner et al. 1975), there has been no study on human endothelial cells which have been suggested to play an important role in the pathogenesis of atherosclerosis (Harker et al. 1978).

We have previously observed prostacyclin synthesis of human cultured endothelial cells (Kawaguchi et al. 1982) and the inhibitory effect of these cells on platelet aggregation (Kawaguchi et al. 1981).

This study was performed to examine the effects of tolbutamide on cultured human endothelial cells with special reference to platelet aggregation.

\section{Materials and Methods}

Cell culture

Endothelial cells were cultured from veins of human umbilical cord using Gimbrone's method (1974). The cord was obtained within $30 \mathrm{~min}$ of normal vaginal delivery and placed in sterile bottles containing phosphate buffered saline (PBS). Perfusion with $200 \mathrm{ml}$ of PBS removed the remaining cord blood. Areas of injuyry on the cord were cut off and 
discarded. The vein was cannulated with polyethylene tubing connected to a syringe and filled with a solution of $0.2 \%$ collagenase (Sigma). The umbilical cord suspended by the syringe was placed in a water bath and incubated at $37^{\circ} \mathrm{C}$ for $15 \mathrm{~min}$. After incubation the collagenase solution containing the cultured cells and $20 \mathrm{ml}$ of the PBS which had been used to flush the empty cord veins were collected in a conical centrifuge tube. Centrifugation at $1100 \mathrm{rpm}$ for $5 \mathrm{~min}$ yielded a small white pellet which was suspeded in culture medium. The culture medium consisted of medium 199 (GIBCO) supplemented with $10 \%$ fetal calf serum (GIBCO), penicillin (100 units $/ \mathrm{ml})$ and streptomycin $(100 \mu \mathrm{g} / \mathrm{ml})$. The centrifugated cells were separated into two $35 \times 10 \mathrm{~mm}$ culture dishes (Falcon) and were grown $37^{\circ} \mathrm{C}$ under $5 \% \mathrm{CO}_{2}, 95 \%$ air until confluence. Primary cultured confluent endothelial cells at 7 days were used for further studies. The number of confluent endothelial cells in one culture dish was $4-4.7 \times 10^{5}$.

\section{Platelet studies}

Venous blood was collected from a healthy, fasting donor who had not taken any drugs for the previous 14 days. Nine volumes of blood were collected in one volume of $3.8 \%$ trisodium citrate dihydrate and platelet rich plasma (PRP) was prepared by centrifugation at $1000 \mathrm{rpm}$ for $10 \mathrm{~min}$. The PRP was then removed and platelet poor plasma (PPP) was produced by further centrifugation at $4000 \mathrm{rpm}$ for another $10 \mathrm{~min}$. Platelet counts were calculated using a Coulter counter. PRP was adjusted with PPP to give a platelet count of $2 \times 10^{5} / 0.5 \mathrm{ml}$. The platelet aggregation test was performed according to the method reported by Oribe et al. (1979) uisng a Bryston aggregometer and adenosine diphosphate (ADP) was used as aggregating agent.

Antiaggregation study by cultured endothelial cells and authentic prostacyclin in vitro

The growth medium was aspirated from the culture dish in which the cultured cells were growing. Cultured cells which had reached confluence were washed five times in Hanks solution and harvested by scraping them from the culture dish with a rubber policeman. After the cultured endothelial cells $\left(2 \times 10^{5} / 0.5 \mathrm{ml}\right.$ Hanks solution) had been preincubated with platelets $\left(2 \times 10^{5} / 0.5 \mathrm{ml} \mathrm{PRP}\right)$ at a final volume of $1.0 \mathrm{ml}$ in an aggregating cuvette at $37^{\circ} \mathrm{C}$ for 5 min with stirring at $1000 \mathrm{rpm}, \mathrm{ADP}(10 \mu \mathrm{M})$ was added. For the control experiment, only $0.5 \mathrm{ml}$ Hanks solution was preincubated with the platelets. Maximal aggregation $(\%)$ and inhibition $(\%)$, under these conditions, were compared with those values obtained under authentic prostacyclin (Ono Pharmaceutical Co.) preincubated with platelets. Threshold dosage for authentic prostacyclin in PRP were $0.5 \mathrm{ng} / \mathrm{ml}, 1.0 \mathrm{ng} /$ $\mathrm{ml}, 5.0 \mathrm{ng} / \mathrm{ml}$ and $10.0 \mathrm{ng} / \mathrm{ml}$ respectively.

\section{Antiaggregation study of cultured endothelial cells treated with tolbutamide}

The confluent cultured endothelial cells were incubated in a culture dish for $24 \mathrm{hr}$ in medium 199 containing tolbutamide (Hoechst Japan Co.) and glucose. Three concentrations of tolbutamide were used in medium 199: $100 \mu \mathrm{M}, 1 \mathrm{mM}$ and $3.4 \mathrm{mM}$ respectively. The control cultured endothelial cells which had been treated with glucose only were also ineubated in medium containing tolbutamide at the three concentrations. Antiaggregation study was performed using these cultured endothelial cells.

\section{RESULTS}

\section{Cell culture}

The cells cultured from human umbilical cord veins were examined by phase contrast and electron microscope. Fresh umbilical venous contents included small clumps of rounded cells which spread to form small epithelioid clusters within 5-6 hr. These clusters incresed in size and gradually combined to form 
incomplete monolayers after 3-5 days of culture. After 7-8 days the cultured cells grew confluent monolayers of flat cells and had a cobble-stone appearance. Weibel-Palade bodies (Weibel and Palade 1964), small cytoplasmic inclusion bodies, were observed in the cultured cells by electron microscope. The cultured cells derived from human umbilical cord veins differed from fibroblast and smooth musclls cells on the basis of cell morphology, growth pattern and the presence of Weibel-Palade bodies. From these findings the cultured cells were identified as endothelial cells.

Antiaggregation study by cultured endothial cells and authentic prostacyclin in vitro

$2 \times 10^{5}$ cultured endothelial cells preincubated with PRP inhibited ADP (10 $\mu \mathrm{M})$-induced platelet aggregation. Also ADP $(10 \mu \mathrm{M})$-induced platelet aggregation was inhibited by authentic prostacyclin, $10.0 \mathrm{ng} / \mathrm{ml}$ (Fig.1). Maximal aggregation $(\%)$ and inhibition $(\%)$ of platelet aggregation from the dose-response curves for cultured endothelial cells and authentic prostacyclin are shown in table

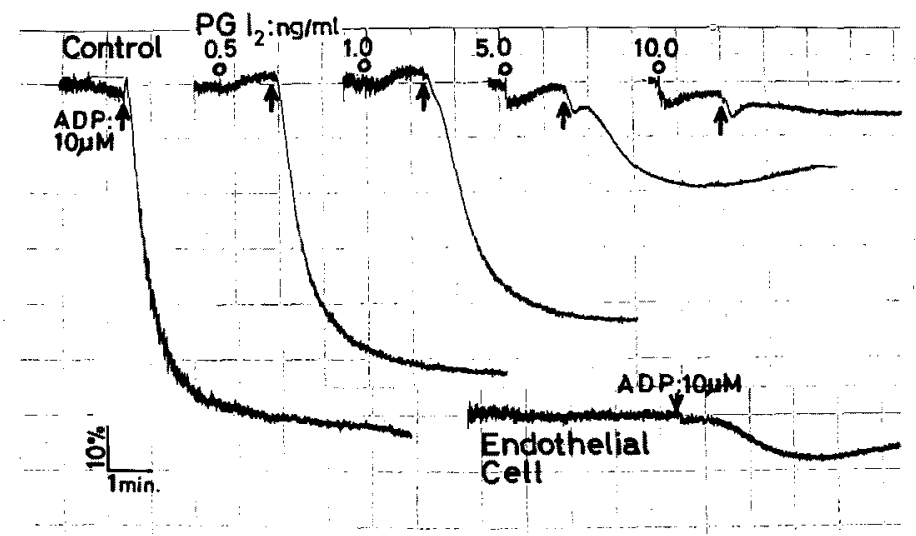

Fig. 1. Comparison of the antiaggregatory effects of authentic prostacyclin and cultured endothelial cells.

TABLE 1. Effects of authentic prostacyclin and cultured endothelial cells on $A D P$-induced platelet aggregation

\begin{tabular}{|c|c|c|c|}
\hline & & Maximal Aggregation ( $\%$ ) & Inhibition $(\%)$ \\
\hline (A) & $\mathrm{ADP}(10 \mu \mathrm{M})$ & 96 & - \\
\hline \multirow[t]{5}{*}{ (B) } & $\begin{array}{l}\text { ADP }(10 \mu \mathrm{M}) \\
\quad+\text { Prostacyclin }(\mathrm{ng} / \mathrm{ml})\end{array}$ & & \\
\hline & 0.5 & 96 & 0 \\
\hline & 1.0 & 88 & 8 \\
\hline & 5.0 & 66 & 31 \\
\hline & 10.0 & 6 & 93 \\
\hline (C) & $\begin{array}{l}\text { ADP }(10 \mu \mathrm{M}) \\
\quad+\text { Endothelial cells }\end{array}$ & 4 & 95 \\
\hline
\end{tabular}


1. $2 \times 10^{5}$ cultured endothelial clles exhibited the same inhibitory effect on ADP $(10 \mu \mathrm{M})$-induced platelet aggregation as authentic prostacyclin, $10.0 \mathrm{ng} / \mathrm{ml}$.

Antiaggregation study of cultured endothelial cells treated with tolbutamide

$100 \mu \mathrm{M}$ tolbutamide had no inhibitory effect on $\mathrm{ADP}(10 \mu \mathrm{M})$-induced platelet aggregation (Fig.2), but $1 \mathrm{mM}$ tolbutamide effected a $25 \%$ decrease in aggregation (Fig.3). At a concention of $3.4 \mathrm{mM}$, tolbutamide caused detachment of endothelial cells from the culture dish.

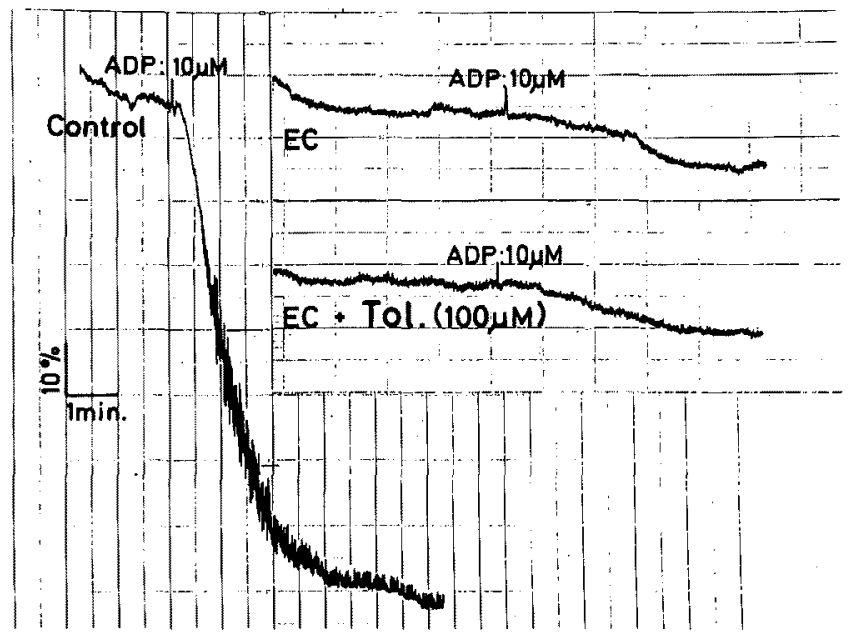

Fig. 2. Effect of $100 \mu \mathrm{M}$ tolbutamide on the platelet inhibitory effect of cultured endothelial cells.

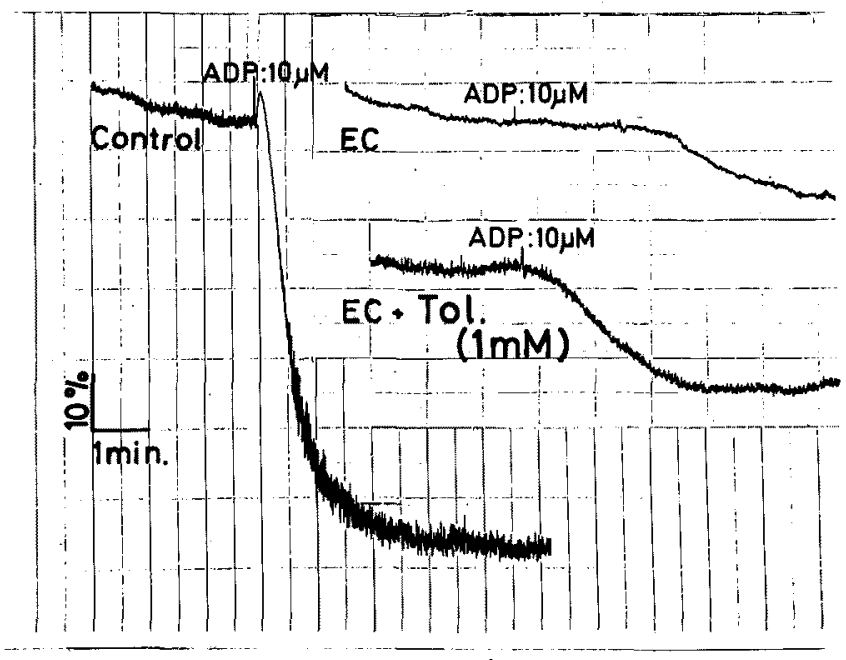

Fig. 3. Effect of $1 \mathrm{mM}$ tolbutamide on the platelet inhibitory effect of cultured endothelial cells. 


\section{Discussion}

The present study was undertaken to examine the effect of tolbutamide on the platelet inhibitory effect of cultured endothelial cells. A reduction in the ability of the endothelial cell to inhibit platelet aggregation is known to result in possible thrombus formation and atherosclerosis.

Our results indicate that tolbutamide does not inhibit platelet aggregation by cultured endothelial cells at concentrations based on conventional dosages. The concentration of tolbutamide used in our study was determined by the report of Melander et al. (1978), which measured the steady-state serum concentration of tolbutamide. Moreover, several studies (Lasseter et al. 1972; Hildner et al. 1975) have reported that a concentration of tolbutamide of $0.1-1.0 \mathrm{mM}$ produces a positive inotropic effect. The authers had previously observed prostacyclin synthesis by cultured endothelial cells, using thin-layer radiochromatography (Kawaguchi et al. 1982). The platelet inhibitory effect of cultured endothelial cells is due to the prostacyclin which they produce. This inhibitory effect was completely blocked by the addition of aspirin $(5 \mu \mathrm{M})$ to the culture medium (Kawaguchi et al. 1981). Therefore this study suggest that tolbutamide in conventional dosages does not inhibit prostacyclin synthesis of endothelial cells.

Abnormalities in platelet function have been reported in diabetics (Oribe 1981). It has also been reported that sulfonylurea causes a decrease in platelet aggregation (Klaff et al. 1981). From these studies, it can concluded that interaction between platelets and blood-vessel walls do not play an important role in the deleterious effects of tolbutamide observed in the UGDP.

\section{References}

1) Harker, L.A., Ross, R. \& Glomset, J.A. (1978) The role of endothelial cell injury and platelet response in atherogenesis. Thrombos. Haemostas., 39, 312-321.

2) Hildner, F.J., Yeh, B.K., Javier, R.P., Fester, A. \& Samet, P. (1975) Inotropic action of tolbutamide on human myocardium. Catheteriz. Cardiovasc. Diag., 1, 47-57.

3) Gimbrone, M.A.Jr., Cotran, R.S. \& Folkman, J. (1974) Human vascular endothelial cells in culture. Growth and DNA synthesis. J. Cell Biol., 60, 673-684.

4) Kawaguchi, K., Oribe, Y. \& Uzawa, H. (1981) Culture of buman endothelial cell and platelet aggregation. Blood \& Vessel, 12, 607-609. (Japanese)

5) Kawaguchi, K., Oribe, Y. \& Uzawa, H. (1982) Prostacyclin production by cultured human endothelial cells derived from umbilical cord. Jpn. Circul. J., 46, Suppl. 3, 763. (Japanese) (Abstract)

6) Klaff, L.J., Kernoff, L., Vinik, A.I., Jackson, W.P.U. \& Jacobs, P. (1981) Sulfonylureas and platelet function. Amer. J. Med., 70, 627-630.

7) Lasseter, K.C., Levey, G.S., Palmer, R.F. \& McCarthy, J.S. (1972) The effect of sulfonylurea drugs on rabbit myocardial contractility, canine purkinje fiber automaticity, and adenyl cyclase activity from rabbit and human hearts. J. clin. Invest., 51, 2429-2434.

8) Melander, A., Sarter, G., Wahlin, E., Scherstén, B. \& Bitzén, P-0. (1978) Serum tolbutamide and chlorpropamide concentrations in patients with diabetes mellitus. Brit. med. J., 21, 142-144. 
9) Oribe, Y. (1981) ADP-induced platelet aggregation and plasma $\beta$-thromboglobulin in diabetes mellitus. Kumamoto med. $J ., 34,39-50$.

10) Oribe, Y., Uzawa, H. \& Nakamura, N. (1979) ADP-induced platelet aggregation in diabetes mellitus. Blood \& Vessel, 10, 523-526. (Japanese)

11) Scientific Advisory Panel of the Executive Committee. Policy Statement. (1979) The UGDP controversy. Diabetes, 28, 168-170.

12) The University Group Diabetes Program. (1970) A study of the effects of hypoglycemic agents on vascular complications in patients with adult-onset diabetes. I. Design, methods and baseline results. II. Mortality results. Diabetes, 19, Suppl. 2, $747-830$.

13) Weibel, E.R. \& Palade, G.E. (1964) New cytoplasmic components in arterial endothelia. J. Cell Biol., 23, 101-112. 